\title{
The global dimension in education and education for global citizenship: genealogy and critique
}

\author{
Greg Mannion $^{\mathrm{a} 1}$, Gert Biesta $^{\mathrm{a}}$, Mark Priestley ${ }^{\mathrm{a}}$ and Hamish Ross ${ }^{\mathrm{b}}$ \\ ${ }^{a}$ The Stirling Institute of Education, University of Stirling, Scotland. \\ ${ }^{b}$ Moray House School of Education, University of Edinburgh, Scotland.
}

(Received November 2009; final version ...)

\begin{abstract}
Encouraged by transnational organisations, curriculum policy makers in the UK have called for curricula in schools and higher education to include a global dimension and education for global citizenship that will prepare students for life in a global society and work in a global economy. We argue that this call is rhetorically operating as a "nodal point' in policy discourse - a floating signifier that different discourses attempt to cover with meaning. This rhetoric attempts to bring three educational traditions together: environmental education, development education and citizenship education. We explore this new point of arrival and departure and some of the consequences and critiques. Key Words: education for global citizenship, environmental education, development education, citizenship education.
\end{abstract}

\footnotetext{
${ }^{1}$ Corresponding author: E-mail: greg.mannion@stir.ac.uk
} 


\section{Introduction}

Over the past decade, in many Western industrialised countries, there has been a rise in calls for educational provision to develop a more global orientation in its pedagogy and curriculum and to equip children and young people with the knowledge, skills and dispositions that will make them more aware of, and engaged with, global issues and phenomena. The resurgence in interest in things global is driven in part by policy initiatives from the education departments of UK countries, the Department for International Development (DfID) and many non-governmental organisations (NGOs). In the UK, the recent resurgence sees a particular uptake of the term global citizenship and the embedding of a 'global dimension' within and across subject areas. UK educational policies suggest that curriculum subjects can and should contribute to the inclusion of this global dimension across the curriculum. The following very similar lists of key concepts underpin the global dimension policies of the various 'home countries' of the UK (Learning and Teaching Scotland [LTS] 2007; Department for Education and Skills [DfES] 2004, 2005; Department for Education, Lifelong Learning and Skills [DELLS] 2006) as depicted below in Table 1.

\begin{tabular}{|l|l|l|}
\hline Scotland (LTS, 2007) & England (DfES, 2004) & Wales (DELLS, 2006) \\
\hline Global Citizenship & Citizenship & Citizenship \& Stewardship \\
\hline Interdependence & Interdependence & Interdependence \\
\hline Conflict resolution & Conflict resolution & Conflict resolution \\
\hline Social Justice & Social Justice & Social Justice \\
\hline Diversity & Diversity & Diversity \\
\hline Sustainable Development & Sustainable Development & Sustainable Change \\
\hline Human Rights & Human Rights & Needs \& Rights \\
\hline
\end{tabular}




\begin{tabular}{|l|l|l|}
\hline Values and world views & Values and perceptions & Values and perceptions \\
\hline
\end{tabular}

Table 1.

While differences exist within these educational policy discourses, we provide evidence of how the reach of the curricular global turn has been homogeneous and impressive in the UK and elsewhere with examples of uptake across all educational sectors, including higher education, and with strong alliances between policy makers, politicians, independent educational centres and NGOs (for example, Oxfam 1997).

Recent research has begun to attribute greater significance to the effect of calls for a global dimension in schools (Dolby and Rizvi 2007; Marshall 2005; Hicks and Holden 2007) but there is less evidence of the actual impact on educational and curricular practice (Critchley and Unwin 2008). Research by Development Education Centres in England has suggested the need for staff development for teachers and the inclusion of terms such as 'global citizenship' in school development plans (see www.local4global.org.uk/schools). A project on global citizenship education within a range of Birmingham schools (L. Davies et al. 2005) has demonstrated that schools can make connections between the wider world and with how young people see their role in society, but found teachers needed further professional development in this regard.

In this paper we analyse what is converging within this new nexus of intentions: we call this convergence the 'curricular global turn' and consider its implications. For us, the rhetorical elevation of 'education for global citizenship' and its insertion into mainstream national official curricula is interesting because it potentially brings together lineages of at least three main sub-fields of education, namely, environmental education (EE), development education (DE) and citizenship education (CE). We note that each of these different educational 'adjectivals' has a 
strong critical or transformative purpose but space does not permit a full exploration here. Our focus is to suggest that in countries such as the UK, 'education for global citizenship' (EGC) is functioning as a nodal point (Laclau and Mouffe 1985) within official educational policy discourse and within these three educational forms. As a 'nodal point', Laclau and Mouffe (1985) suggest it works as a privileged reference point (or signifier) that attempts to partially fix meaning and bring together different discourses. A nodal point is also malleable and unstable discourse, varying depending on the context and how power is gained in organising a socio-discursive field. EGC, we suggest, works as such a nodal point. In doing so it also serves as a place of arrival of several different strands of thinking and pedagogical practice. These strands have heretofore struggled for official curriculum space, often being driven from outside formal education with support from NGOs and various forms of activism. As a nodal point, 'education for global citizenship' (EGC) on the one hand sets out to allow diverse meanings to converge while subordinating other meanings. Like an airport hub for meaning making, it also creates distinctive points of departure and new agendas. We will explore these lineages, arrivals and departures through our analysis.

\section{Lineages ... and convergences?}

First, we present lineages of three educational sub-fields, namely environmental education (EE), development education (DE) and citizenship education (CE). As the task here is to look across three substantive fields, the lineages are necessarily glossed and informed by other commentators' analyses. Each of these fields has its own literatures and space does not permit a comprehensive treatment of all the nuances, linkages and trajectories over time between and among them. EE, DE and CE traditions also include, for example, education for sustainability or education for 
sustainable development, peace education, global education, multi-cultural education, and international education. We take EE, DE and CE in turn, noting how they overlap and work in tension and make their own curricular global turns.

\section{Lineage 1: Environmental Education}

Nature study ... fieldwork ... conservation education ... environmental education

... global education (1980s version)... education for sustainable development

(ESD) / education for sustainability (EfS)... education for global citizenship

$(\mathrm{EGC}) ?$

Palmer (1998) chronicles the shifts in environmental education (EE) from nature study, through fieldwork, urban studies, conservation education and into the period in the 1980s when environmental education sought stronger links with development education in order to take cognizance of the political dimensions of environmental issues. Gough (2002) lists a number of key education texts from the 1980s growing out of the EE field that encouraged pedagogies based on 'thinking globally, acting locally' - knowing and caring about the global dimensions and significance of environmental problems and issues. After the Rio Summit of 1992, the action report, Agenda 21, called on education to work towards sustainability by acknowledging the interlinked nature of economic, social and environmental issues. This, it was envisaged, would be best achieved encouraging community participation, partnership working among agencies, systems thinking, and so on.

Reid (2002) suggests that education for sustainability might be regarded as the 'offspring' of environmental education and development education, though Sauvé (2005a) recognizes at least 15 trends in EE representing a very large diversity of 
models, of which ESD is but one. While various critical approaches are flourishing theoretically - for example, the eco-socialist (Huckle 2008), place-based (Gruenewald 2003) and poststructuralist (Gough 2002) - Sauvé and Berryman (2005) have "witnessed a rising tide of almost purely instrumental views" (230) within EE as it became more globalised after Agenda 21. Stables (1996) used the term 'paradoxical compound policy slogan' to describe education for sustainable development. So, Stables and Scott (2002) caution that efforts to pin down sustainable development are challenging (with already slippery terms 'sustainable' and 'development' being coupled in this way) and suggest that lists (as in Table 1 above) seeking to name its scope and reach will assume 'a false consensus'. Education for global citizenship is also an attractive term that is likely to have similar appeal across diverse interest groups (Stables and Scott 2002) and results in attendant paradoxes.

Within EE, terms such as 'global' and the 'eco-citizen' have already been used in an effort to bring greater coalescence between DE and EE sometimes under EfS and ESD umbrellas. Gough and Scott (2006) provide examples of what they call a technocratic approach to solving the human-environment problem through an emphasis on the 'environmentally-responsible citizen'. Critics (Sauvé and Berryman 2005; Gough and Scott 2006) suggest that some calls for EE to embrace Education for Sustainable Development are more like efforts to 'close a circle' with a desire for unnecessary consensus around pre-ordained aims and instrumentalist measurement of progress (Sauvé and Berryman, 2005). However, some socially critical approaches within the sub-field of EE are ready to accept a form of 'education for global citizenship' as a goal (Huckle 1999), and pressure is mounting in policy circles to embed it in initial teacher education and schools' curricula internationally. Thus for EE, the arrival of EGC may be, on the one hand be yet another attempt to 'close the 
circle', or on the other, potentially, an attempt to use the construct of sustainability more critically to "extend citizens rights and responsibilities across time space and generations and species" (Huckle 1999, 39). While much of the field of EE foregrounds citizenship, Gough and Scott (2006) ask us to critically reflect on a number of issues including the possible roles for citizens in liberal democracies especially in relation to sustainable development and the differential economic power enjoyed by citizens of different countries and by different citizens within countries.

\section{Lineage 2: Development Education}

Third-world pedagogy ... development education ... global education ... education for global citizenship (EGC)?

Scheunpflug and Asbrand (2006) trace how 'Third World pedagogy', 'development education' (DE) and, more recently, 'global education' have clear historical lineage, with one approach leading fairly linearly on to the next. Today, Scheunpflug and Asbrand (2006, 35) assert that global education (GE):

$$
\text { has established itself as an educational field which provides a 'pedagogical }
$$
reaction to the developmental state of world society' working within the normative premise of overcoming inequality by being orientated towards a model of global justice" ... "the aim of global education is to support the learners' development in terms of acquiring adequate competencies for life in a world society, preparing for an uncertain future and acquiring competencies to deal with complexity and uncertainty.

Since we are concerned with the convergence of various fields, we should note that DE educators and theorists have also expressed their unease with 'sustainability' and worried over the possibility that social justice in third world countries might be 
subordinated in an overly environmental focus. Scheunpflug and Asbrand (2006) suggest EfS needs the perspective of global education to bring worldwide issues of justice alongside the concerns of environmental education, and because sustainable environmental protection needs to take on board that we live in a complex globalised world. Despite these trends, the two fields (DE and EE) have maintained fairly distinct fields of practice, though some advance the view that EGC may be a nexus for their convergence.

As the DE field becomes more professionalised and government funded in the UK, DE has become more obviously 'global' (adopting the term in titles of conferences, names of DE centres and in journals). Indeed, 'global education' has virtually superceded DE as a term. In contrast, Hicks (2003) suggests a nomenclature that is more nuanced, with 'global education', 'global dimension' and 'global citizenship' working as a triad of constructs for all forms of the DE tradition. O'Loughlin and Wegimont (2007) suggest that global and development education and awareness-raising on development issues has recently 'come in from the cold' because there is now a recognition that a global development agenda requires an informed and educated public in the developed world. This trend is supported by transnational initiatives such as the United Nations Decade of Education for Sustainable Development. Within this frame, DE (or 'global education') may be one small step away from accepting EGC as a keynote idea, affording more legitimacy to the field and greater policy leverage. But this approach may render DE less political, a view supported by Marshall (2005) who found NGO-based global education activists both welcomed the opportunities to come in from the margins and link with the higher-status citizenship education, and also worried that it might ghettoise DE and/or lead to a loss of its critical edge. A more reformist and activist notion is offered by Oxfam $(2006,3)$ 
who see the global citizen as someone who is (among other things) 'outraged by social injustice' and 'is willing to act in order to make the world a more equitable and sustainable place'. The latter emphasis on the affective and political response to issues and events is reminiscent of more traditional NGO-led 'global education'.

\section{Lineage 3: Citizenship Education}

Civic education (modern studies)... citizenship education ... education for citizenship ... international education (and perhaps entrepreneurial education)... education for global citizenship (EGC)?

Citizenship education rose to the surface of educational policy debates in England with the Crick Report and various curricular reforms in the UK more widely. In Scotland, Peters (cited in Blee and McClosky, 2003) argues that "... globalisation without citizenship is politically blind and citizenship without globalisation is theoretically naïve". It is perhaps no wonder, then, that citizenship has become strongly coupled with 'global' by those who wish to harness it as a response to globalisation and those who wish to give education for citizenship (in Scotland, where it is not a 'subject') or 'citizenship education' (in England, where it is a subject area) contemporary relevance.

I. Davies et al. (2005) explore the differences between citizenship and global education. They suggest that such a coming together (as depicted in Figure 1 below) is timely with the demise of the welfare state and current perspectives on globalisation. EGC would allow us to look beyond old barriers that have separated citizenship education (which has emerged as a form of social science), and global education (which emphasizes political activity beyond the study of political science or the practice of community involvement). Within the field, different theories of citizenship 
(liberal, republican, cosmopolitan) provide starting points for ways of working towards justice, democracy and sustainability (see Huckle 2008). Following Dobson's view of post-cosmopolitan citizenship, Huckle (2008) argues for environmental and ecological citizenship. According to Huckle, we have non-contractual, non-reciprocal, and unilateral duties to others, because citizens' actions in the private as well as public sphere (through consumption for example) are seen to affect other people in far-flung places. By this view, new forms of EGC would require the individual citizen to see the private sphere as political. This approach seeks to runs some risks. Firstly, it rests on the view that it is possible for individuals, through education, to come to 'reasonable agreement' or understanding about who and what needs to happen, if they are to fairly respond in their context by, say, reducing their carbon footprint. Secondly, the risk is that ecological citizenship focuses more on the private sphere where folk are expected to privately and voluntarily 'do the right thing', while larger structures and process potentially continue with 'business as usual'. Lastly, even if teachers were ready to take on a values-laden approach to citizenship (and we have evidence that they are not in L. Davies et al. 2005), coming to understand what is 'the right thing' with students may be especially problematic as there are many competing perspectives. Evans et al. $(2009,29)$ comment that in EGC notions of social justice are less evident in teaching and learning practices. They also recognize that EGC is often seen as a means to build "a competitive workforce and contribute to the economic growth of the nation" [by] "preparing students with the knowledge, skills and competencies required to compete in the global economy" $(2009,23)$.

We have used the construct of lineage to show how each educational sub-field might respond to the official curricular turn towards the global via the rhetorical policy slogan, or nodal point, of 'education for global citizenship' (see figure 1 below). 


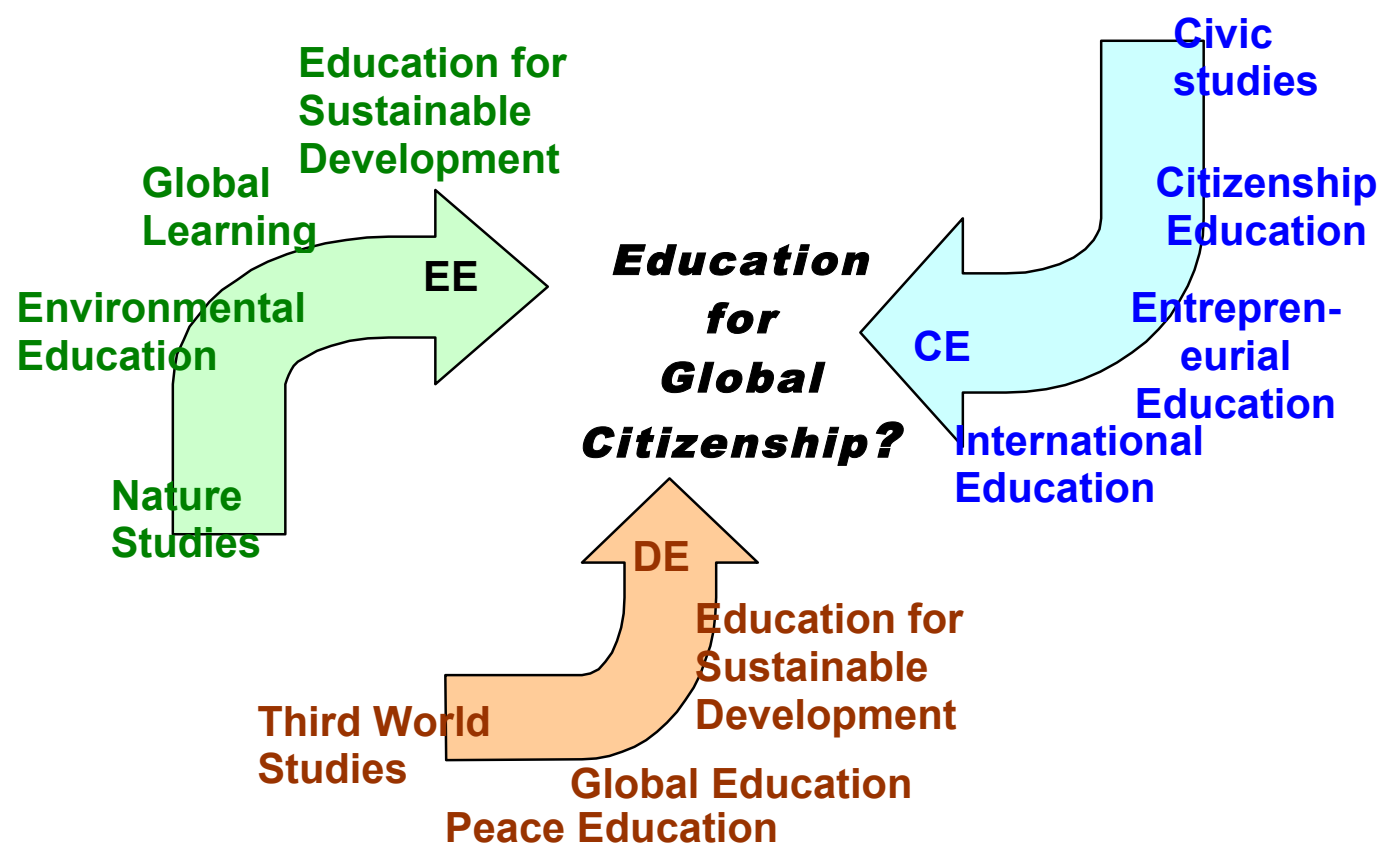

Figure 1. The EE, DE and CE lineages potentially converging on a nodal point in their respective discourses.

While there is anecdotal evidence of a curricular global turn being made in practice in $\mathrm{DE}, \mathrm{EE}$ and $\mathrm{CE}$, we do have stronger evidence of EGC working as a nodal point in some of the academic commentaries. However, this emphasis is most striking in official educational policy relating to EGC. Rhetorically, the official curricular global turn seeks to bring three educational traditions together under EGC by seeking alignments with traditional EE, DE and CE purposes. For EE, EGC offers (among many things) a way of foregrounding a civic response to current global environmental concerns perhaps; for DE, EGC is similarly attractive as it potentially advances global justice and provides some in the GE field a more mainstream curricular space; for CE, EGC perhaps offers a way to advance cosmopolitan forms of citizenship (Held and McGrew, 2005). For all three adjectival educations there are potential synergies (across ecological citizenship and ESD for example) but as we have seen, there are detractors in 
each field. In practice, as each of the three traditions potentially arrives and accepts or resists EGC for its own reasons, there are voices of concern, potential gains and losses, and new points of departure. We next explore what the main messages are within official global curricular turn, how the EGC discursive nodal point is rhetorically created, and what the concerns might be.

\section{The official 'curricular global turn'}

In this section, our analysis provides a reading of the outwardly stated purposes of some official schools-focused educational policies of the 'curricular global turn'. We argue that the official turn towards the global is founded on a rationale that requires students to make an economic and a cultural response to perceived current circumstances in ways that mask possible political concerns. The call is generally phrased as "the challenge of preparing students for life in a global society and work in a global economy".

In the next exemplar, we notice the foregrounding of economic and cultural challenges brought about by global processes and events and the sense of urgency about the perceived need to respond to an already changed reality:

We know the world is changing fast. New ideas, new technologies and new economic and social imperatives at work are bringing nations and regions closer together both as partners and as competitors. [...] it's not "the world of the future". It's the world of right now - and certainly the world into which our children and students will enter. If the United Kingdom is to continue to be a significant global player - economically and culturally - then our education system has to look increasingly outward. We are in the business of preparing our children and students to leave our schools for a globally interconnected world, where a customer, a partner, an adviser, a competitor, a colleague, a collaborator is just as likely to be in Tokyo or Brussels or Houston as in Edinburgh or 
Swindon. (DfES 2004, 3)

In 2001, Scottish First Minister Jack McConnell brought together similar economic and cultural arguments for international education (and here, as above, the economic argument comes first):

Why do we need to be 'internationally educated'?

'The answer to that question seems so obvious as to be scarcely necessary. After all, we are already European citizens, with rights and responsibilities as such - but most of us are still comparatively ignorant of what these are. We must earn a living within an increasingly global economy - but, as yet, our understanding of what that signifies is limited. There are major issues of race, citizenship, cultural diversity, religious differences, environmental protection, sustainable food supplies, deprivation, human rights, technological advance and many others now facing the world as a whole - but we largely still lack the knowledge, understanding and skills that would enable us to think critically about them, make truly informed decisions and take appropriate action at a personal, local, national or international level. (Scottish Executive 2001, italics added)

The cultural dimension of the response made available by the curricular global turn is also expressed in many other schools-focussed policy documents:

Equally, if the United Kingdom is to remain a stable society our children will need an increased knowledge about other cultures, systems and practices and the skills to work with and respond to their similarities and differences. [...] For our children to be comfortable in a socially inclusive world, where they see diversity of language, culture and race as enriching rather than threatening, urgent classroom issues have to be addressed, now rather than in the future. (DfES 2004, 3-4)

We note that the educational response demanded from students is expressly economic and cultural, not political. By enhancing the global dimension we will - it is 
vouched - bring cultural stability and enable cultural threats to be turned into features we need to work with and understand as enriching. Similarly, the three key goals within the document "Putting the World into World-Class Education" (DfES 2004, 6) are:

- "Equipping children and adults for a global society and economy.

- Working with other nations and regions to their benefit and ours.

- Maintaining an education system that can further our global economic objectives."

In Canada, also, Evans et al. $(2009,23)$ accept that EGC is in part a means to build "a competitive workforce and contribute to the economic growth of the nation" [by] "preparing students with the knowledge, skills and competencies required to compete in the global economy" though the authors strive to offer alternative framings. The analysis of official policies suggests the curricular turn towards the global is premised on students solely making an economic and cultural response to a particular form of global reality, as perceived by education policy makers. We suggest the loosely masked underlying political imperative behind this rests on a view of what globalisation is, and how its effects are valued.

Globalisation is a contested idea, but it is generally characterised as being a product of many different forces involving the economic, cultural and political domains. In our exemplars, the two dominant themes are solely about making an economic and cultural response to a fixed context, rather than any consideration of the possibility of making a political response to a context that might be changeable. We also note that in these texts, the world is not just 'becoming global' but already is so. This approach suggests the educational policy response (the official curricular global turn) is to prepare citizens to participate in an already changed, unified globalised 
world, typically captured through phrases like 'work and live in a global economy'. Others, however, argue globalisation is not so unified, widespread or even unprecedented historically and may be in fact a political project of the developed world. Whatever one's position with respect to these dissonant voices, a more critical questioning of the rhetoric of globalisation is warranted, especially if political participation is required in an effort to transform it into a more equitable social transformation. However, our analysis suggests that the current official 'curricular global turn' offers one dominant model of globalisation that is desired for us and for others, and rests on a view of onward economic development of Western countries. Following Lingard's post-colonial analysis (2009), a relational and reflexive critique of the educational policy field of EGC may reveal it is not, ironically a 'global' project for all, but rather a more localised political project led by some countries that supports the 'social imaginary' of globalisation for their own ends. This analysis calls us to notice our position with respect to globalisation, and critique education's response via official policies for EGC.

\section{Re-reading Education for Global Citizenship}

Gough (2002) reminds us that 'global education' first made an impact in the 1980s with a range of texts such as Pike and Selby's Global Teacher, Global Learner. He notes that "we may not be able to speak - or think - from outside our own Eurocentrism" $(2002,1233)$ and that phrases such as 'think local, act global' are likely to be framed within our Western ways of thinking and acting. He draws attention to the ways in which a 'limited range of meanings are sedimented' in culturally located texts and practices. Gough uses post-colonialist and anti-imperialist standpoints (via Harding and Turnbull) to argue that all knowledges are situated and performed within local 
conditions and cultural values, though some ideas clearly 'travel' further beyond the local. In this light, 'global citizenship education' is particularly worth interrogating for signs that it too is being used to tacitly advance particularly Western perspectives over other cultures' views. In supporting the view of globalisation as an already arrived entity and attempting to educate graduates and pupils to participate in the global market economy, it could be argued that the official take on the curricular global turn is a localised feature of modern Western countries that perhaps seeks to transcend and occlude other alternative, local ('non-global' or anti-globalisation) perspectives.

Jickling and Wals have earlier worried over a similar educational initiative (education for sustainable development), seeing its expression as part and parcel of "the powerful wave of neo-liberalism rolling over the planet, with pleas for 'market solutions' to educational problems and universal quality-assurance schemes, [which] are homogenizing the educational landscape" (Jickling and Wals 2007, 2). While EGC may be offering a sincere and well-intentioned set of purposes for education, we need to look closer and more critically to see if it is functioning as an ideological concept that travels well, but is working (sometimes inadvertently, sometimes concertedly) as a tool of Western modern imperialism; to homogenize and prescribe goals, thereby reducing "the conceptual space for self-determination, autonomy, and alternative ways of thinking" (4). We suspect that this homogeneity of approach within official policy across the home countries of the UK is indicative of a wider process of homogenization across a number of countries. Buying into this homogenization could mean that "many educators have become agents in a trend towards economic globalisation" (Jickling and Wals 2007, 6). The curricular turn towards the global may be offering a very contemporary particularly western gaze on the world. It is interesting to note that the language in these policy documents fail to foreground how they are located in a 
particular part of the world. Gough suggests that ignoring how ideas, such as taking 'global dimension' in education, are a 'culturally shaped' representation of a reality 'is an imperialist act - an act of attempted intellectual colonization" (Gough 2002, 1228) and asks "how can we think globally without enacting some form of epistemological imperialism?". This critique reminds us to check whether our ethnocentric positioning prejudices our reading of the global curricular turn.

'Global citizenship education', as we have seen, is a new paradoxical policy slogan that potentially offers points of arrival and departure for at least three adjectival fields of education, each with their own critical sub-traditions. It is our appraisal that this nodal point in the discourse is not arising by chance in the West as it responds to threats that are perceived to be mainly cultural and economic. Interestingly, in the 1980s, 'global education' as an approach did not get picked up within mainstream curriculum policy or practice in the way that it is now receiving attention in many OECD countries. OECD commentators suggest that 'global education' is moving from the periphery to the centre of national educational policy agendas (O'Loughlin and Wegimont 2007), and this is because of the recently heightened sense of new threats and exigencies in a changed global context that foreground our economic, climatic and cultural interdependence. Our analysis of the official policy discourse around the curricular global turn in education suggests that EGC is best understood as a reaction to the presumed 'fact' of the development of a certain kind of global world economy and society or, the need for one, or a fear that it is threatened. Perhaps, the taken for granted assumption is that global citizenship is really an educational response apposite to developed countries: because it is 'us' who, after all, supposedly 'lead' in the processes of globalisation; or perhaps because we need a form of international solidarity for our success in the face of threats. 


\section{Re-mixing citizenship in a global space}

The analysis prompts us to ask: What other visions for the education of global citizens can we imagine? What pitfalls and alternatives to EGC are there when we consider education in a global manner?

One response within the critical tradition of DE comes from Andreotti (2007). She reminds us that an elite global professional managerial class (consisting of people in or coming from the First and the Third Worlds), often embedded in international non-governmental organizations, may work to reproduce ethnocentric and developmentalist mythologies onto the 'less developed' countries they seek to help 'develop'. Andreotti distinguishes between a 'soft' and a 'critical' global citizenship education project. Her critique draws on Spivak's work to suggest that a 'soft' form of EGC initiatives runs the risk of supporting an on-going epistemic violence of imperialism of the so-called 'First World' over the 'Third World', which is encouraged through development discourse to 'catch up' and become more civilised; in effect becoming more 'global' / 'globalised' (Andreotti 2007). In contrast, the critical approach seeks to uncover the processes that hide difference, create inequalities, maintain exploitation. The starting point is from a view that globalisation is asymmetrical and suggests that terms such as global citizen, if fixed or pre-given, may be a neo-colonial imposition. She suggests that through critical literacy and reflexivity that participants can analyse their own positions in complex structures, with a view to changing them and their attendant assumptions, identities, attitudes and power relations. Andreotti's suggestion is that through critical analysis and reflexivity we might be able to expose, challenge and ultimately change and overcome existing power relationships. This approach runs the risk of relying too much on modern notions of emancipatory and 
empowering education - notions that themselves remain caught in the colonial way of thinking (which Andreotti correctly challenges with regard to the global citizenship agenda) (see Biesta 1998; 2010a). In this regard there is, therefore, not only a need to engage critically with notions of citizenship that inform the different discourses of global citizenship, but also to work critically and creatively at new ways of 'doing' education that respond adequately to the new condition of citizenship in a global context.

\section{Conclusion and some caveats}

We have noted the convergences in the lineages of environmental education, development education and citizenship education under the umbrella of the global citizenship education. We have pointed to the role of EGC as a nodal point in the discourses that potentially reorients three traditions to some of their own ends and to some new ones. We have commented on the manner in which this policy nexus brings NGOs, governments and international (economic) development together within a perspective on the world that is very much of its time and place in the West. In particular, we suggest that bringing together heretofore often radical, NGO-led, curricular approaches 'in from the cold' is, in policy terms at least, driven by a need to make a response to perceived cultural and economic threats. There is a danger here that NGOs may be becoming complicit with a hegemonic desire to 'civilise' less developed countries with developed world models. Indeed, Oxfam's own vision for the education of the global citizen sits within the view of itself as a quite powerful transnational actor that potentially supports a normative liberal agenda in their support of freer trade (see Berry and Gaby 2009). 
Our analysis raises concerns with respect to the idea of educating for global citizenship. One concern relates to the way global citizenship education seeks to "wrap up' environmental and development agendas within a new found citizenship agenda. This may lead to role of the 'responsible citizen' being mainly defined in official curricular documents in cultural and economic terms (i.e., doing work for the economy and doing good work in/for the community). The justice-oriented citizen may be easily obfuscated within the curricular global turn.

A further arising caveat relates to the understanding of citizenship as a competence (i.e., as a set of skills and dispositions that individuals can posses) versus seeing citizenship as an ongoing practice, as something people do (see Biesta 2009; Lawy and Biesta 2006). The tendency in a lot of policy literature, but also in education, is to see citizenship first of all as a competence. This then defines the task of citizenship education as that of fostering the acquisition/development of these competences (and this is exactly what is being done in the European context; in UK citizenship education this approach is known in terms of the acquisition of so-called 'citizenship dimensions'). There are a couple of problems with the competence approach. One is that it individualises citizenship by seeing it in terms of what individuals have, rather than in terms of what individuals do together. It individualises by assuming that if all citizens have the right competences, democracy will simply happen (see Biesta 2007). Jickling and Wals $(2007,8)$ see this approach as a deficit model of transmissive education of the citizen who [must be] "obedient, deferential, and compliant as they take their place within hierarchical and authoritative social structures and power relationships".

If we think of citizenship as something that constantly needs to be achieved (and this can never be guaranteed) then we need to emphasise the process of citizenship 
itself. This has implications for education. In the outcome perspective, global education becomes the producer of global citizens; in the process perspective the first question to ask is what citizenship practices are possible within schools and society more generally, and only then to ask what and how students might learn from such practices (see Biesta 2010b).

What we are hopefully contributing to this debate, through our genealogical analyses of the terms and discourses within policy documents. As a nodal point in various discourses we suggest that EGC is an attempt to fix some meanings through converging ideas from selected aspects of the EE, DE and CE lineages while subordinating others. Our concern is that what is surfacing may not be the most appropriate approach for our purposes if we seek to truly engender a critical perspective and active responses in learners. We have explored how contemporary concerns with our competitiveness as a 'global economy' in a world concerned with international security and stability are possible drivers of the new-found convergence under the umbrella term, EGC. This in itself should raise our sceptical antennae: why this term, and why now and why this new proposed alliance among stakeholders? But finally we warn that more critical practices of EGC require 'us' in the West to take a reflexive look at our position vis the majority world. Of course schools will make their responses, as they always do, through the ways they translate policy into practice (and this warrants further empirical enquiry). In official policy terms, in the headlong rush to 'close the circle' (Sauvé 2005) under the global citizenship umbrella, we would warn against the erasure of the rich tapestry of eco-socially critical approaches found in the lineages of EE, DE and CE ... at least, that is, until the next nodal point in the discourse emerges. 
Acknowledgements: We are grateful for the support of the International Development Education Association of Scotland (http://www.ideas-forum.org.uk/) whose network events with the Initial Teacher Education Institutions around Scotland inspired us to engage in this task. We are also grateful for the helpful comments from both anonymous reviewers and the feedback we received from colleagues at seminars and conferences when we presented these emerging ideas.

Biographical Notes.

\section{References}

Andreotti, V. 2007 An ethical engagement with the other: Spivak's ideas on education. Critical Literacy, Theories and Practices 1, no. 1: 69-79.

Berry, C. and C. Gaby 2009 Transnational political action and 'global civil society' in practice: the case of Oxfam. Global Networks 9, no. 3: 339-358.

Biesta, G.J.J. 1998. "Say you want a revolution..." Suggestions for the impossible future of critical pedagogy. Educational Theory 48, no.4: 499-510.

Biesta, G.J.J. 2007. Education and the democratic person: Towards a political understanding of democratic education. Teachers College Record 109, no.3: 740769.

Biesta, G.J.J. 2009. What kind of citizenship for European Higher Education? Beyond the competent active citizen. European Educational Research Journal 8, no. 2: 146157.

Biesta, G.J.J. 2010a. A new 'logic' of emancipation: The methodology of Jacques Rancière. Educational Theory 60, no.1: 39-59.

Biesta, G.J.J. 2010b. How to exist politically and learn from it: Hannah Arendt and the problem of democratic education. Teachers College Record 112, no.2: 558-577.

Blee, H. and A. McClosky 2003. Perspectives on the provision of education for citizenship in Scotland and France, including a small-scale comparative study of pupil experience in Brittany and Scotland. Paper presented at the European 
Conference on Educational Research, September 17-20 in Hamburg, Germany. Available online http://www.leeds.ac.uk/educol/documents/00003495.htm. (accessed March 2010).

Critchley, M. and R. Unwin 2008. Whole-school development and the global dimension/global citizenship: Capturing models of practice across the UK.

Development Education Centre South Yorkshire. Available online www.decsy.org.uk (accessed June 2008).

Davies, I., Evans, M. and Reid, A. 2005. Globalising citizenship education? A critique of 'Global Education' and 'Citizenship Education'. British Journal of Educational Studies 53:1, pp 66-89.

Davies, L., C. Harber, and H. Yamashita 2005. Global citizenship education: The needs of teachers and learners, Centre for International Education and Research, University of Birmingham.

DELLS 2006. Education for sustainable development and global citizenship: A strategy for cction. Cardiff: Department for Education, Lifelong Learning and Skills.

DfES 2004. Putting the world into world class education: An international strategy for education, skills and children's services. London: Department for Education and Skills.

DfES 2005. Developing the global dimension in the school curriculum, $2^{\text {nd }}$ ed. London: Department for Education and Skills.

Dolby, N. and Rizvi, F. 2007. Youth moves: Identities and education in global perspective. London: Routledge.

Evans, M., L. A. Ingram, A. MacDonald, and N. Weber 2009. Mapping the "global dimension" of citizenship education in Canada: The complex interplay of theory, practice, and context. Citizenship, Teaching and Learning 52, no. 2: 16-34. 
Gough, N. 2002. Thinking/acting locally/globally: Western science and environmental education in a global knowledge economy. International Journal of Science Education 24, no. 11: 1217-1237.

Gough, S. and W. Scott 2006. Education and sustainable development: A political analysis, Educational Review 58, no. 3: 273-290.

Gruenewald, D. 2003. The best of both worlds: A critical pedagogy of place. Educational Researcher 32, no. 4: 3-12.

Held, D. and A. McGrew, eds. 2005. The global transformation reader: An introduction to the globalization debate. 3rd ed. Cambridge: Polity Press.

Hicks, D. and C. Holden, eds. 2007. Teaching the global dimension: Key principles and effective practice. London: Routledge.

Hicks, D. 2003. Thirty years of global education: a reminder of key principles and precedents. Educational Review 55, no. 3: 131-141.

Huckle, J. 1999. Environmental education - between modern capitalism and postmodern socialism: A reply to Lucie Sauvé. Canadian Journal of Environmental Education 4: 36-45.

Huckle, J. 2008. Sustainable development. In The Sage Handbook of Education for Citizenship and Democracy, eds. J. Arthur, I. Davies, I. and C. Hahn, 342-354. London: Sage Publications.

Jickling, B. and E.A.J. Wals 2007. Globalization and environmental education: looking beyond sustainable development. Journal of Curriculum Studies, 40, no. 1: 1-21.

Laclau, E. and C. Mouffe 1985. Hegemony and socialist strategy. London: Verso.

Lawy, R.S. and G.J.J. Biesta 2006. Citizenship-as-practice: The educational implications of an inclusive and relational understanding of citizenship. British Journal of Educational Studies 54, no. 1: 34-50. 
Lingard, B. 2009. Researching education policy in a globalized world: Theoretical and methodological considerations. Yearbook of the National Society for the Study of Education 108, no. 2: 226-246.

LTS 2007. The global dimension in the curriculum: Educating the global citizen. Glasgow: Learning and Teaching Scotland.

Marshall, H. 2005. Developing the global gaze in citizenship education: Exploring the perspectives of global education NGO workers in England. International Journal of Citizenship and Teacher Education 1, no. 2: 76-92.

Oxfam 2006. A curriculum for global citizenship: a guide for schools. London: Oxfam GB.

http://www.oxfam.org.uk/education/gc/files/education_for_global_citizenship_a_gui de for schools.pdf (accessed March 2010).

O’Loughlin, E. and L. Wegimont 2007. Global education, public awareness-raising and campaigning on development issues: An overview of evaluation practice and policy. OECD: Bonn, 19-20 March.

http://www.oecd.org/dataoecd/43/59/38405962.pdf (accessed July 2009).

Palmer, J.A., 1998. Environmental education in the 21st century: Theory, practice, progress, and promise. London: Routledge.

Reid, A. 2002. Discussing the possibility of education for sustainable development. Environmental Education Research 8, no. 1: 73-79.

Sauvé, L. 2005. Currents in environmental education: Mapping a complex and evolving pedagogical field. Canadian Journal of Environmental Education 10: 1137.

Sauvé, L. and T. Berryman 2005. Challenging a "closing circle": Alternative research agendas for the ESD Decade. Applied Environmental Education and 
Communication 4: 229-232.

Scheunpflug, A. and B. Asbrand 2006. Global education and education for sustainability. Environmental Education Research 12, no. 1: 33-46.

Scottish Executive 2001. An international outlook: educating young Scots about the world. Edinburgh: Scottish Executive.

Stables, A. 1996. Paradox in compound educational policy slogans: evaluating equal opportunities in subject choice. British Journal of Education Studies 44, no. 2: 159167.

Stables, A. and A. Scott 2002. The quest for holism in education for sustainable development. Environmental Education Research 8, no. 1: 53-61. 